\title{
ARGVMENTVM VOLVMINIS SEPTIMI
}

Compendia ....................... XI

Index $\mathrm{V}$ : Res potiores, imprimis grammatica et rhetorica . . . . . 1

Addenda et corrigenda

1. Supplementum praefationis . . . . . . . . . . . . . . 263

2. Compendia addenda Auctores . . . . . . . . . . . . . . . . . . . . . . . 268

Tituli librorum . . . . . . . . . . . . . . . . . . . . . . 269

3. Nominum virorum doctorum supplementum . . . . . . . . 269

4. In textu et apparatu critico corrigenda et supplenda . . . . . . . 270

5. Testimoniis addenda . . . . . . . . . . . . . . . . 337 
